\title{
CrimRxiv
}

\section{Rural Crime and Community Safety}

\section{Vania Ceccato}

Published on: Sep 08, 2015

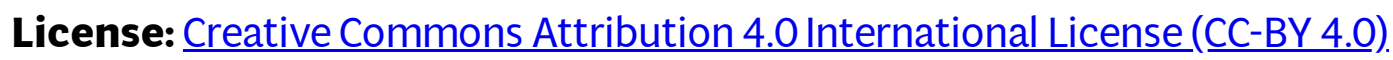


